\title{
Influences of agricultural phenology dynamic on land surface biophysical process and climate feedback
}

\author{
LIU Fengshan ${ }^{1,2}$, CHEN Ying ${ }^{2}$, SHI Wenjiao ${ }^{1,3}$, ZHANG Shuai ${ }^{1,3}$, "TAO Fulu ${ }^{1,3}$, \\ *GE Quansheng ${ }^{1,3}$
}

1. Key Laboratory of Land Surface Pattern and Simulation, Institute of Geographic Sciences and Natural Resources Research, CAS, Beijing 100101, China;

2. Fujian Agriculture and Forestry University, Fuzhou 350002, China;

3. College of Resources and Environment, University of Chinese Academy of Sciences, Beijing 100049, China

\begin{abstract}
Response and feedback of land surface process to climate change is one of the research priorities in the field of geoscience. The current study paid more attention to the impacts of global change on land surface process, but the feedback of land surface process to climate change has been poorly understood. It is becoming more and more meaningful under the framework of Earth system science to understand systematically the relationships between agricultural phenology dynamic and biophysical process, as well as the feedback on climate. In this paper, we summarized the research progress in this field, including the fact of agricultural phenology change, parameterization of phenology dynamic in land surface progress model, the influence of agricultural phenology dynamic on biophysical process, as well as its feedback on climate. The results showed that the agriculture phenophase, represented by the key phenological phases such as sowing, flowering and maturity, had shifted significantly due to the impacts of climate change and agronomic management. The digital expressions of land surface dynamic process, as well as the biophysical process and atmospheric process, were improved by coupling phenology dynamic in land surface model. The agricultural phenology dynamic had influenced net radiation, latent heat, sensible heat, albedo, temperature, precipitation, circulation, playing an important role in the surface energy partitioning and climate feedback. Considering the importance of agricultural phenology dynamic in land surface biophysical process and climate feedback, the following research priorities should be stressed: (1) the interactions between climate change and land surface phenology dynamic; (2) the relations between agricultural phenology dynamic and land surface reflectivity at different spectrums; (3) the contributions of crop physiology characteristic changes to land surface biophysical process; (4) the regional differences of climate feedbacks from phenology
\end{abstract}

Received: 2017-03-05 Accepted: 2017-04-13

Foundation: China Postdoctoral Science Foundation, No.2016M601115; National Natural Science Foundation of China, No.41571088, No.41371002

Author: Liu Fengshan, $\mathrm{PhD}$, specialized in agricultural meteorology and regional climate change.

E-mail: liufs.11b@igsnrr.ac.cn

"Corresponding author: Tao Fulu, Professor, E-mail: taofl@igsnrr.ac.cn

Ge Quansheng, Professor, E-mail: geqs@igsnrr.ac.cn 
dynamic in different climate zones. This review is helpful to accelerate understanding of the role of agricultural phenology dynamic in land surface process and climate feedback.

Keywords: agricultural phenology; land surface biophysical process; land surface process model; climate feedback

\section{Introduction}

Land surface processes and climate are tightly coupled. The distribution of vegetation and associated land surface characteristics are strongly controlled by the climate, and the climate is modulated by land surface processes through which surface features change the exchange of energy and water in the boundary layer and the chemical composition of the atmosphere (including $\mathrm{CO}_{2}, \mathrm{CH}_{4}$, and $\mathrm{O}_{3}$ ). Previous studies highlight the impacts of global change on land surface processes; however, the feedbacks of land surface processes to climate change are poorly understood (Bright et al., 2015). Affected by global climate change (e.g., increased temperature and precipitation variability) and human management (e.g., land use and land management changes), surface processes have become an important driver of climate change at local, regional, and global scales with elevated variation ranges and intensities (Pielke et al., 2007; Kowalczyk et al., 2016; Liu et al., 2016a; Liu et al., 2016b). Surface process dynamics further regulate the structure and function of an ecosystem via long-term impacts on climate (McGuire et al., 2006) and potentially threaten the food safety and quality of life of human beings. A deep understanding of the influences of land surface dynamics on surface biophysical processes and climate feedbacks is expected to improve studies of the interaction between global change and land surface processes.

Closely related to human life, farmland is one of the ecosystems most frequently disturbed by climate change and human activity. Methods to increase grain production, including increases in farmland area and per unit yield, have greatly changed the surface processes of agricultural ecosystems. Previous studies have shown that land management and land cover changes have impacts of similar magnitude on the surface temperature via surface albedo and roughness mechanisms (Luyssaert et al., 2014) and that specific management measures exert modulations on temperature, precipitation, and the atmospheric environment in a given period primarily via surface energy partitioning mechanisms (Lobell et al., 2006; Zhang et al., 2013; Jeong et al., 2014; Bagley et al., 2015; Mueller et al., 2016). The demand for grain will continue to increase due to population growth and rising living standards in the future. The primary method to protect food production security will be to improve the yield per unit area under the conditions of limited land resources and scarce high-yield farmland. The regulation function and spatial-temporal characteristics regarding the influences of agricultural phenology dynamics on land surface biophysical processes and climate feedbacks are therefore an important subject when mitigating climate change and securing food safety.

Phenology is an important concept in the description and digital expression of an ecological system. Much attention had been paid to the contribution of natural phenology, especially, in forests, to surface biophysical processes and climate feedbacks (Penuelas et al., 2009; Korner and Basler, 2010; Dai et al., 2013). The advanced leaf-out of temperate forests, boreal forest, Mediterranean shrubs and grass control many feedbacks of vegetation to the climate system by influencing the seasonality of albedo, surface roughness length, canopy 
conductance, and fluxes of water and energy (Richardson et al., 2013). Less effort has been made to discuss the influence of agricultural phenology on surface biophysical processes and climate feedbacks. By defining the critical sowing, seedling, flowering, mature, and harvest periods, agricultural phenophase provide an objective research basis for human controlled ecosystems. In the study of surface biophysical processes, agricultural phenophases are closely tied to surface processes, the heat and water balance, and material exchanges between crop-air boundaries. For example, the interannual dynamics of the agricultural phenophase is closely related to the normalized difference vegetation index (NDVI) and the leaf area index (LAI) (Guillevic et al., 2002). Maize albedo was different in the germination, flowering, and mature stage and influenced by the planting date (Oguntunde and van de Giesen, 2004). The simulation accuracy of the heat, water, and carbon budget in agro-systems depended on simulation errors of the crop phenology in land surface process models (Chen et al., 2015).

Agricultural phenology, by controlling the exchange of materials, heat, and momentum at the air-land boundary, not only provides a basis for studying the history of climate change but also influences the degree and direction of future climate change. Ge et al. (2014) reconstructed the spring phenology index over the past 170 years in East China; this variation provides critical information for the relationship between plant phenology and influence of long-term climate change on surface biophysical processes (Zheng et al., 2015). Coupling static and dynamic phenology in the CanESM2 model shows that a longer growing season causes higher plant productivity and biomass. The dynamic phenology resulted in a warmer spring controlled by the decreased surface albedo in North America and offset the fertilization effect of carbon dioxide via a temperature increase and a rainfall reduction under the RCP8.5 scenario (radiant energy increased by $8.5 \mathrm{~W} \mathrm{~m}^{-2}$ by 2100) in southeastern America (Garnaud and Sushama, 2015). These study results highlight the importance of dynamic phenology in climate feedbacks via biophysical processes.

This paper reviews the following aspects concerning the agricultural phenology dynamics: the existence of agricultural phenology dynamics, the expression of agricultural phenology in land surface process models, and its influence on surface biophysical processes and climate feedbacks. Four problems are also refined for future studies. This review highlights the importance of surface phenology dynamics in land surface processes and atmospheric circulation models.

\section{Existence of agricultural phenology dynamics}

Wheat, maize, and soybeans are the most widely planted crops (Leff et al., 2004). According to data on crop production and harvest areas, the world's five main grain production bases and crops include maize in the Midwestern United States, soybeans in southeastern South America, maize in West Africa, and wheat in Central and East Asia (Bagley et al., 2012). However, studies of the phenological characteristics of these three crops have been concentrated in developed agricultural areas such as China, America, and Europe, and less progress has been made in West Africa and Central Asia (Table 1). The observed data in these regions showed that the phenological phenomenon of wheat, maize, and soybeans had changed significantly over the past half century. For example, the planting dates of maize and soybean advanced by 10 days and 12 days, respectively, from 1981-2005 in America (Sacks and 
Table 1 Characteristics of phenological change and controlling factors for staple crops around the world

\begin{tabular}{|c|c|c|c|}
\hline Country & Crop & Phenology variation & Drivers \\
\hline $\begin{array}{l}\text { China (Tao et } \\
\text { al., 2012; Xiao } \\
\text { et al., 2013; } \\
\text { 2015) }\end{array}$ & Winter wheat & $\begin{array}{l}\text { Sowing, seedling, and dormant } \\
\text { stage delayed by } 1.5,1.7 \text {, and } 1.5 \\
\text { days/decade, respectively. } \\
\text { Spring green up, flowering, and } \\
\text { mature stage advanced by } 1.1,2.7 \text {, } \\
\text { and } 1.4 \text { days/decade, respectively. }\end{array}$ & $\begin{array}{l}\text { Increased temperature reduces the } \\
\text { growth period, variety renewal with } \\
\text { higher GDD extends the reproductive } \\
\text { stage, and reduced day length extends } \\
\text { the vegetative period. }\end{array}$ \\
\hline $\begin{array}{l}\text { China (Tao et } \\
\text { al., 2014; Wang } \\
\text { et al., 2016; } \\
\text { Xiao et al., } \\
\text { 2016) }\end{array}$ & Summer maize & $\begin{array}{l}36.6 \% \text { of sites with extended ma- } \\
\text { ture stage, and } 41.1 \% \text { of sites with } \\
\text { extended growth period. } \\
\text { Reproductive growth period ex- } \\
\text { tended by } 2.4-3.7 \text { days/decade. }\end{array}$ & $\begin{array}{l}\text { Increased average temperature shortens } \\
\text { the growth period. } \\
\text { Variety renewal delays the flowering } \\
\text { and mature stages. } \\
\text { Advancement of planting date to adapt } \\
\text { to increased temperature. }\end{array}$ \\
\hline $\begin{array}{l}\text { China (Wang et } \\
\text { al., 2016) }\end{array}$ & Maize & $\begin{array}{l}\text { Advanced planting, jointing, and } \\
\text { flowering stages. } \\
\text { Delayed mature stage. } \\
\text { Shortened vegetative period. } \\
\text { Prolonged reproductive period. }\end{array}$ & $\begin{array}{l}\text { Global warming speeds up the devel- } \\
\text { opment of maize and shortens the } \\
\text { growth period. } \\
\text { Precipitation reduces growth period to a } \\
\text { certain extent. } \\
\text { Variety renewal extends growth period. }\end{array}$ \\
\hline $\begin{array}{l}\text { America (Sacks } \\
\text { and Kucharik, } \\
\text { 2011) }\end{array}$ & Maize & $\begin{array}{l}\text { Sowing stage advanced by } 4.2 \\
\text { days/decade. } \\
\text { Duration from sowing to harvest } \\
\text { increased by } 5 \text { days/decade. } \\
\text { Duration from mature to harvest } \\
\text { shorted by } 3 \text { days/decade. }\end{array}$ & $\begin{array}{l}\text { GDD increased by } 14 \% \text { in the repro- } \\
\text { ductive stage. } \\
\text { Maize variety with longer growth pe- } \\
\text { riod. } \\
\text { Interaction with more irrigation, added } \\
\text { fertilizer, and variety renewal. }\end{array}$ \\
\hline $\begin{array}{l}\text { America (Sacks } \\
\text { and Kucharik } \\
\text { 2011) }\end{array}$ & Soybeans & $\begin{array}{l}\text { Sowing stage advanced by } 4.9 \\
\text { days/decade. } \\
\text { Harvest stage advanced by } 4.9 \\
\text { days/decade. }\end{array}$ & $\begin{array}{l}\text { Higher temperature in favor of sowing } \\
\text { advancement and long duration of ma- } \\
\text { turity. } \\
\text { Variety renewal with longer reproduc- } \\
\text { tive period. }\end{array}$ \\
\hline $\begin{array}{l}\text { Northern and } \\
\text { Central Europe } \\
\text { (Olesen et al., } \\
\text { 2012) }\end{array}$ & $\begin{array}{l}\text { Gramineae } \\
\text { (wheat, oats, } \\
\text { and maize) }\end{array}$ & $\begin{array}{l}\text { Sowing stage advanced by } 1-3 \\
\text { weeks. } \\
\text { Flowering and mature stages ad- } \\
\text { vanced by } 1-3 \text { weeks. }\end{array}$ & $\begin{array}{l}\text { Model parameter setting based on } 1500 \\
\text { site records: development from sowing } \\
\text { to flowering stage depends on tempera- } \\
\text { ture and day length for oat and wheat } \\
\text { and on temperature for maize and de- } \\
\text { velopment from flowering to mature } \\
\text { stage depends on temperature. }\end{array}$ \\
\hline $\begin{array}{l}\text { Spain (Oteros et } \\
\text { al., 2015) }\end{array}$ & $\begin{array}{l}\text { Cereal crops } \\
\text { (oats, wheat, } \\
\text { rye, barley, and } \\
\text { maize) }\end{array}$ & $\begin{array}{l}\text { Phenology in spring advanced for } \\
\text { winter wheat. } \\
\text { Flag leaf sheath swelling advanced } \\
\text { by } 30 \text { days/decade. } \\
\text { Flowering stage advanced by } 10 \\
\text { days/decade. }\end{array}$ & $\begin{array}{l}\text { Temperature prior to certain phenology } \\
\text { was the main factor. } \\
\text { Human intervention mitigates the im- } \\
\text { pact of phenology change on yield. }\end{array}$ \\
\hline $\begin{array}{l}\text { Germany } \\
\text { (Chmielewski et } \\
\text { al., 2004) }\end{array}$ & Maize & $\begin{array}{l}\text { Sowing, seedling, and initial har- } \\
\text { vest stages advanced by } 1.7,3.3 \text {, } \\
\text { and } 1.3 \text { days/decade, respectively. } \\
\text { Duration from sowing to seedling } \\
\text { reduced by } 1.6 \text { days/decade. } \\
\text { Duration from seedling to harvest } \\
\text { increased by } 2.1 \text { days/decade. }\end{array}$ & $\begin{array}{l}\text { Increased spring temperatures make } \\
\text { sowing in advance possible. } \\
\text { Strong warming in May accelerates } \\
\text { plant growth and imposes serious ef- } \\
\text { fects on the seedling stage. }\end{array}$ \\
\hline $\begin{array}{l}\text { Kazakhstan (de } \\
\text { Beurs and } \\
\text { Henebry, 2004) }\end{array}$ & Wheat & NDVI peak 4-7 days in advance. & $\begin{array}{l}\text { Increased GDD. } \\
\text { Collapse of the Soviet Union. }\end{array}$ \\
\hline
\end{tabular}


ses of the phenology observation data had reached significant levels at China's agricultural meteorological sites (Tao et al., 2012; 2014; Xiao et al., 2013; 2015; 2016; Wang et al., 2016). The consistent change rule of agricultural phenology includes the advancement of planting dates and the lengthening of the filling period (Sacks and Kucharik, 2011; Olesen et al., 2012; Tao et al., 2014). Prolonged filling period increases the time of accumulation for organic matter, and advanced planting date benefits the extension of the crop growth period and improves the process of dry matter fixation. The variations in magnitudes were different for different regions. However, this does not alter the fact that agricultural phenology change exists, but rather provides a strong motivation to explore its mechanisms.

The main reasons of agricultural phenology dynamics include global climate change represented by temperature increases and artificial management measures represented by variety renewal (Mirschel et al., 2005; Eyshi Rezaei et al., 2017). The raising temperature has made it possible to advance the planting date in spring and delay the harvest in autumn. However, the development rates of crops and the accumulation of the growing degree day (GDD) have also been sped up, which shortens the duration between sowing and maturity and potentially threatens the yield output with increasing temperatures. Purposefully selecting crop variety with longer growth periods and higher demand for the GDD will effectively extend the growth season and make full use of the increasing agricultural climate resources (Zhou, 2015). For the purpose of yield improvement, the extension of the reproductive stage, matched with proper management measures such as fertilization, irrigation, and plant density, is a pronounced characteristic of agricultural phenology. The raising temperature dominates the agricultural phenology fluctuation in areas with less human intervention (e.g., Kazakhstan (de Beurs and Henebry, 2004)), whereas human activities offset or even reverse the negative effects of climate and gain in yield by prolonging specific key development stages in agriculture-advanced regions. The phenology of winter wheat and summer maize are simultaneously influenced by the rotation system in China, which means that winter wheat can only be sowed after the harvest of summer maize in the late autumn and summer maize can only be seeded after winter wheat is reaped in the late spring. Therefore, the agricultural phenophase is influenced by the previous cereal.

\section{Monitoring of agricultural phenology dynamics and its digital expression in land surface process models}

The monitoring methods of agricultural phenology dynamics primarily include ground observation method, remote sensing monitoring method, and model simulation method (Fan et al., 2016). Ground observation method, which has the advantages of high time precision and easy operation and the disadvantage of spatial-temporal limitations, is the basic methodology of phenology studies, which uses artificial survey approach to record the crop growth rhythm at individual and small area scales (Schwartz et al., 2006). Remote sensing monitoring method is rooted in the nature of the emission, reflection, and absorption of electromagnetic waves for all target objects. The surface spectrum information of crop population characteristics can be perceived by sensors. This method needs to be combined with ground observation data for localization and contains certain errors (Chen and Wang, 2009; Ge et al., 2010). Model simulation method refers to the physiological mechanisms of plant growth rhythms at the individual and population level and the establishment of a phonological 
model to study the spatial-temporal variation of plant phenology. The parameterization and digitalization of agricultural phenology provides a convenient pathway to examine the interactions between the environment and phenology and is helpful to uncover the mechanisms of crop growth. Errors are the main obstacle in models simulating surface phenology dynamics (Morin et al., 2009).

The data and processes obtained from ground observation and remote sensing monitoring methods are affected by external environmental factors, and the resulting uncertainty makes it difficult to verify the role of phenology in surface biophysical processes and climate feedbacks. Model simulation method is commonly used in land surface process and climate change studies, which has an obvious advantage for the digital expression of crop growth (Gervois et al., 2004; Chen et al., 2015). At the spatial scale, model simulation method can meet the requirements of various scales from micro, local, and regional to the global scales used in atmospheric studies and provides matter and energy fluxes in the boundary layer inside and outside the research area due to lateral exchanges. At the temporal scale, not only can the contribution of historical phenology changes be analyzed but also guidance can be provided for the direction of crop planting and the regulation of climate change trends in the future.

Environmental and artificial control schemes are the two primary methods to express agricultural phenology dynamics in land surface process models. Environmental control schemes are based on the relationship between environmental variables (especially, the meteorological environment) and phenology; a specific phenophase will occur when the environmental variables reach a certain threshold. GDD and day length are the key factors for controlling crop growth. In the CLM3.5-CornSoy model, the development from the seedling, leaf-out, to filling stages of maize and soybeans is controlled by GDD, whereas the harvest is controlled by the day length (Chen et al., 2015). The development of winter wheat is subject to temperature, jarovization, and the light cycle (Wang and Engel, 1998). The crop's germination and subsequent progress is set by the GDD and the planting date in the SiBcrop model (Lokupitiya et al., 2009; Lei et al., 2010). Artificial control schemes refer to parameters which stay constant under external environmental conditions but are determined by the model developer and user. For example, the threshold value of the GDD for specific phenophases is different and is set according to the actual situation or research objective (Chen et al., 2015). The parameters, including the optimum and extreme temperatures used in the GDD calculation and the conversion criteria of agricultural phenology, have subjectively settled attributes and values according to the region (Tsarouchi et al., 2014).

The existing simulation model of agricultural phenology and growth usually has a detailed algorithm for the phenological characteristics and physiological processes. Examples include the CROPGRO and CERES crop models, with detailed physiology and phenological characteristics, which can be used to estimate the photosynthesis, dry matter distribution, and heat and water fluxes driven by weather, soil, and management data (Shi et al., 2012). Gervois et al. (2004) and de Noblet-Ducoudr'e et al. (2004) coupled a crop model (STICS) with a global dynamic vegetation model (ORCHIDEE), the simulation accuracy of the carbon and water exchange was improved by outputting more reliable growth processes of maize, wheat, and soybeans. The development of crop models provides a convenient method for the digital expression of the phenology and quantitative feedbacks to the environment. 


\section{Impacts of agricultural phenology dynamics on surface biophysical processes}

The impacts of coupling surface phenology processes with land surface models are multifaceted. First, the phenology forms the basis parameters of the crop growth. Coupled crop models express the growth and development processes of crops, which involve the development of phenophases and morphology. Phenophase development refers to the changes in the growth stages and biomass distribution patterns. Morphology development refers to the beginning and ending of various organs in the life cycle of a crop and provides information concerning leaves, tiller, and grain (Chen and Xie, 2011). Second, phenology dynamics result in changes in the surface processes. The partitioning of photosynthetic carbon into parts of a crop is closely associated with the seasonal development stages in models (Lei et al., 2010), where partitioning into roots changes the processes of the soil water supply; partitioning into leaves changes the LAI and canopy structure; partitioning into the stem changes the plant height; and partitioning into fruits constrains the changes of other organs and surface characteristics. Phenology, by controlling the crop LAI and structure, is therefore an important factor in surface morphological processes. Third, physiological characteristics are also affected by the phenology. In particular, the canopy conductance and Rubisco activity are major mechanisms for photosynthesis, respiration, and evaporation in models (Lokupitiya et al., 2009; Tsarouchi et al., 2014). Therefore, agricultural phenology dynamics exert a large impact on both morphological and physiological parameters and provide a computational basis for LAI, surface albedo, radiation budget, and moisture movement at a certain precision in land surface process models.

Responses of surface biophysical processes to agricultural phenology dynamics have the following basic characteristics. Early in phenology, the components of surface biophysical processes (such as surface albedo, net radiation, and latent heat flux) are mostly controlled by the soil, which is less covered by leaves; however, the contribution from crop increases sharply with fast crop growth. The crop height and canopy structure are simple, the surface roughness length and zero plane displacement stay lower, and the momentum exchange process is relatively stable. In the full grown stage of phenology, the optimal status of crop height and canopy, surface roughness length, zero plane displacement, net radiation, and latent heat flux reaches a peak and the surface albedo and the sensible and ground heat fluxes are maintained at lower levels for longer times. At the end of phenology, crop physiological processes decrease significantly, which causes net radiation mainly allocated into sensible heat flux. The abscission and removal of the crop in the harvest stage sharply changes the surface biophysical processes and significantly reduces the variables of surface roughness length, zero plane displacement, and albedo, and the crop residue has a certain protective effect on the soil moisture and evaporation. The observation data of surface heat and water fluxes in winter wheat at Weishan station, Shandong province, reveal that wintering stage $<$ heading and jointing stage $<$ filling and mature stage for net radiation and latent heat, and that heading and jointing stage $<$ filling and mature stage $<$ wintering stage for sensible heat (Yuan et al., 2010). The small latent heat reflected in the winter wheat primarily allocates the net radiation into sensible heat in the winter. The more complex canopy structure and LAI seen in the filling and mature stage as opposed to the heading and jointing 
stage is good for the capture of solar irradiation and transpiration.

Many crop models or agricultural phenology algorithms have been coupled to land surface process models in studies of surface processes at site and regional scales. According to the collected data (Table 2), there were seven crop growth models and five agricultural phenology algorithms coupled with nine land surface process models to provide the surface dynamics of agro-ecosystems. Revised land process models have realized simulations of a variety of farming systems (e.g., monoculture, crop rotation, and fallow), za model to an agro-ecosystem is enhanced, as is the digital expression ability of the heat and water balance in different agricultural surfaces. For example, the SiBcrop model improved its simulation precision of the American wheat, soybean, and maize ecosystems and the Chinese winter wheat-summer maize rotation system (Lokupitiya et al., 2009; Lei et al., 2010).

The influence of historical phenology dynamics on surface heat and water balances can possibly be realized in land surface model simulations by including a surface phenology algorithm that provides additional details of the surface biophysical processes. Earlier planting date increased (decreased) the latent (sensible) heat flux in June and reduced the interval time from maturity to harvest by enhancing the net radiation in October in American maize fields (Sacks and Kucharik, 2011). Prolonged phenology imposed little impact on surface biophysical processes overall; however, the maximum magnitude of the change can reach $45 \mathrm{~W} \mathrm{~m}^{-2},-20 \mathrm{~W} \mathrm{~m}^{-2}$, and $-25 \mathrm{~W} \mathrm{~m}^{-2}$ for latent, sensible, and soil heat fluxes, respectively, when the NDVI is increased by 0.1 in the Agro-IBIS model (Bagley et al., 2015). This phenomenon is due to the low proportion of phenologically changed periods in the total growth period, and the variation of the surface biophysical processes primarily occur during times of phenological fluctuation. Phenology dynamic also impacts the surface albedo. Prolonged phenology, by multiple reflections in a canopy with enhanced LAI and canopy height (Hammerle et al., 2008), decreases the surface albedo. The exposure of soil after harvest enlarges the contribution of soil reflection to the total albedo, which decreases (increases) if the soil reflection is lower (higher) (Erb et al., 2016).

Impacts of phenology dynamics on the surface energy balance via coupling with the crop model in land surface process models become an important part of climate feedbacks from surface processes. However, previous studies have focused on the influence of surface morphological changes (e.g., LAI and NDVI) on the surface albedo and heat and water balances. The dynamics of physiological characteristics and controlled energy partitioning have always been ignored, and much less attention has been given to the interaction of meteorological data and phenological changes. Under the background of climate change, changes in crop physiological characteristics are guaranteed to improve the photosynthetic efficiency at a specific phenology and production (Balota et al., 2008; Sharma and Pannu, 2008; Xiao et al., 2012; Aisawi et al., 2015; Koester et al., 2016). Changes in the stomatal characteristics, especially, at the reproductive stage via controlling the exchange of water and $\mathrm{CO}_{2}$ in the atmosphere, will certainly alter the canopy conductance and the latent ratio with the influence of meteorological conditions. A systematic study on the responses of surface biophysical processes to crop morphological and physiological changes under specific meteorological conditions will be helpful to correctly evaluate the contributions of agricultural phenology dynamics to climate change. 
Table 2 Contribution of land surface and crop model coupling to understanding surface energy and water balance

\begin{tabular}{|c|c|c|c|}
\hline Model $^{\mathrm{a}}$ & Crop type & Result & Reason \\
\hline $\begin{array}{l}\text { Agro-IBIS } \\
\text { Dynamic crop } \\
\text { growth model(Sacks } \\
\text { and Kucharik, 2011) }\end{array}$ & $\begin{array}{l}\text { Maize and } \\
\text { soybean in } \\
\text { America }\end{array}$ & $\begin{array}{l}\text { Agricultural phenology dynamic changed the } \\
\text { surface heat and water balance; } \\
\text { Earlier planting increased latent heat in June, } \\
\text { reduced maturity-harvest duration, and increased } \\
\text { net radiation in October. }\end{array}$ & $\begin{array}{l}\text { Using GDD to express } \\
\text { phenology change }\end{array}$ \\
\hline $\begin{array}{l}\text { BATS } \\
\text { CERES3.0 (Chen } \\
\text { and Xie, 2011) }\end{array}$ & $\begin{array}{l}\text { Farmland in } \\
\text { China }\end{array}$ & $\begin{array}{l}\text { Canopy interception, transpiration, evaporation, } \\
\text { latent and sensible heat fluxes had significantly } \\
\text { impacted; } \\
\text { Decrease the systematic error of LAI and surface } \\
\text { moisture; } \\
\text { Increase the simulation accuracy of surface flux. }\end{array}$ & $\begin{array}{l}\text { Addition of the process } \\
\text { of crop development and } \\
\text { growth }\end{array}$ \\
\hline $\begin{array}{l}\text { BATS } \\
\text { CERES-Maize } \\
\text { (Tsvetsinskaya et } \\
\text { al., 2001) }\end{array}$ & $\begin{array}{l}\text { Maize in } \\
\text { America }\end{array}$ & $\begin{array}{l}\text { Latent heat changed by } 30 \%-45 \% \text {, sensible heat } \\
\text { changed by } 20 \%-35 \% \text { with LAI changed from } 5 \\
\text { to } 1 \text {; } \\
\text { The contribution of evaporation and transpiration } \\
\text { to latent was influenced by LAI. }\end{array}$ & $\begin{array}{l}\text { Phenophase and organic } \\
\text { matter accumulation and } \\
\text { allocation process based } \\
\text { on physiology }\end{array}$ \\
\hline $\begin{array}{l}\text { CLASS } \\
\text { Carbon and nitrogen } \\
\text { model (Chang et al., } \\
\text { 2014) }\end{array}$ & $\begin{array}{l}\text { Farmland in } \\
\text { Canada }\end{array}$ & $\begin{array}{l}\text { Increase the determination coefficient between } \\
\text { simulated and observed data of NEP; } \\
\text { More rational distribution process of organic } \\
\text { matter. }\end{array}$ & $\begin{array}{l}\text { Addition of the agricul- } \\
\text { tural phenological } \\
\text { scheme and management } \\
\text { measure }\end{array}$ \\
\hline $\begin{array}{l}\text { CLM } \\
\text { CornSoy (Chen et } \\
\text { al., 2015) }\end{array}$ & $\begin{array}{l}\text { Maize and } \\
\text { soybean in } \\
\text { America }\end{array}$ & $\begin{array}{l}\text { Closely connection between carbon flux and } \\
\text { phenology in simulation; } \\
\text { Better correlation between simulated and ob- } \\
\text { served data for LAI, energy and } \mathrm{CO}_{2} \text { flux. }\end{array}$ & $\begin{array}{l}\text { The expression of } \\
\text { emergence-filling stage } \\
\text { and filling-harvest stage } \\
\text { using GDD; } \\
\text { Remove the restriction } \\
\text { to maximum LAI. }\end{array}$ \\
\hline $\begin{array}{l}\text { CLM } \\
\text { Agricultural phe- } \\
\text { nology model (Levis } \\
\text { et al., 2012) }\end{array}$ & $\begin{array}{l}\text { Maize, soy- } \\
\text { bean and cere- } \\
\text { als in North } \\
\text { America }\end{array}$ & $\begin{array}{l}\text { More real LAI, spring planting, autumn harvest } \\
\text { in simulation; } \\
\text { Better representation of latent heat in lower LAI } \\
\text { period }\end{array}$ & $\begin{array}{l}\text { The seasonal dynamics } \\
\text { of agricultural phenol- } \\
\text { ogy and carbon alloca- } \\
\text { tion driven by tempera- } \\
\text { ture. }\end{array}$ \\
\hline $\begin{array}{l}\text { ISAM } \\
\text { Dynamic crop } \\
\text { growth model (Song } \\
\text { et al., 2013) }\end{array}$ & $\begin{array}{l}\text { Maize-soybean } \\
\text { rotation sys- } \\
\text { tem America }\end{array}$ & $\begin{array}{l}\text { Dynamic growth model improves simulation of } \\
\text { seasonal change of LAI, canopy height, root } \\
\text { depth, soil moisture absorption and evaporation, } \\
\text { fluxes of energy, water and carbon. }\end{array}$ & $\begin{array}{l}\text { The containment of the } \\
\text { stress of light, water and } \\
\text { nutrient on crop } \\
\text { dynamic; } \\
\text { Increased simulation } \\
\text { accuracy of LAI sea- } \\
\text { sonal dynamic; } \\
\text { Better simulation of soil } \\
\text { moisture absorption and } \\
\text { transpiration. }\end{array}$ \\
\hline $\begin{array}{l}\text { JULES } \\
\text { InfoCrop (Tsarouchi } \\
\text { et al., 2014) }\end{array}$ & $\begin{array}{l}\text { Farmland in } \\
\text { India }\end{array}$ & $\begin{array}{l}\text { Simulation error of evapotranspiration decreased } \\
\text { from } 7.5-24.4 \text { to } 5.4-11.6 \mathrm{~mm} \text { month }^{-1} \text { in wet } \\
\text { season and from } 10-17 \text { to } 2.2-3.4 \mathrm{~mm} \mathrm{month}^{-1} \text { in } \\
\text { dry season }\end{array}$ & $\begin{array}{l}\text { Addition of the crop } \\
\text { growth model }\end{array}$ \\
\hline $\begin{array}{l}\text { JULES } \\
\text { SUCROS (Van den } \\
\text { Hoof et al., 2011) }\end{array}$ & $\begin{array}{l}\text { Farmland in } \\
\text { Europe }\end{array}$ & $\begin{array}{l}\text { Significantly increased correlation between } \\
\text { simulated and measured data in farmland; } \\
\text { Better expression in the spatial-temporal charac- } \\
\text { teristics of crop growth; } \\
\text { The importance of crop structure and phenology } \\
\text { to land-air interaction. }\end{array}$ & $\begin{array}{l}\text { Dynamic crop growth; } \\
\text { The expression of } \\
\text { phenology from planting } \\
\text { to harvest. }\end{array}$ \\
\hline $\begin{array}{l}\text { LPJ } \\
\text { DGVMs (Bondeau } \\
\text { et al., 2007) }\end{array}$ & $\begin{array}{l}\text { Global farm- } \\
\text { land }\end{array}$ & $\begin{array}{l}\text { Better expression in planting date, canopy sea- } \\
\text { sonal dynamic of crop in temperate zone; } \\
\text { Farmland expansion decreased transpiration by } \\
5 \% \text {, and increased evaporation by } 40 \% \text {. }\end{array}$ & $\begin{array}{l}\text { Parameterization of } \\
\text { phenology and its con- } \\
\text { nection with LAI. }\end{array}$ \\
\hline
\end{tabular}


(Continued)

\begin{tabular}{|c|c|c|c|}
\hline Model $^{\mathrm{a}}$ & Crop type & Result & Reason \\
\hline $\begin{array}{l}\text { ORCHIDEE } \\
\text { STICS (Gervois et al., } \\
2004 \text { ) }\end{array}$ & $\begin{array}{l}\text { Winter wheat and } \\
\text { maize in France and } \\
\text { America }\end{array}$ & $\begin{array}{l}\text { Better simulation of evapotranspi- } \\
\text { ration, biomass accumulation } \\
\text { process in different climatic zones. }\end{array}$ & $\begin{array}{l}\text { Added simulation of LAI, nu- } \\
\text { trition stress, and plant height; } \\
\text { Improved simulation of organic } \\
\text { matter distribution, water } \\
\text { stress, and carboxylation. }\end{array}$ \\
\hline $\begin{array}{l}\mathrm{SiB} 2 \\
\text { Agricultural phenol- } \\
\text { ogy model } \\
\text { (Lokupitiya et al., } \\
\text { 2009) }\end{array}$ & $\begin{array}{l}\text { Wheat, soybean, } \\
\text { maize in America }\end{array}$ & $\begin{array}{l}\text { Better simulation of the beginning } \\
\text { and ending of growth season, } \\
\text { harvest, seasonal dynamic of } \\
\text { rotation system; } \\
\text { Increased LAI and carbon flux. }\end{array}$ & $\begin{array}{l}\text { Phenological scheme and cor- } \\
\text { responding physiological } \\
\text { parameters for specific crop. }\end{array}$ \\
\hline $\begin{array}{l}\text { SiB2 } \\
\text { Agricultural phenol- } \\
\text { ogy model (Lei et al., } \\
2010 \text { ) }\end{array}$ & $\begin{array}{l}\text { Winter } \\
\text { wheat-summer } \\
\text { maize rotation sys- } \\
\text { tem in North China } \\
\text { Plain }\end{array}$ & $\begin{array}{l}\text { Precisely simulation of LAI, } \\
\text { carbon flux, latent flux, soil water } \\
\text { content and yield }\end{array}$ & $\begin{array}{l}\text { Phenological scheme and } \\
\text { corresponding physiological } \\
\text { parameters for specific crop. }\end{array}$ \\
\hline
\end{tabular}

Note: Land surface process model in front, crop model behind

\section{Climate feedback of agricultural phenology dynamic by adjusting surface biophysical process}

Temperature-phenology response function (Kumudini et al., 2014) is usually applied to study the impacts of climate on agricultural phenology in general circulation model, such as $\mathrm{GDD}_{10,30}$, the temperature in the range of $10-30^{\circ} \mathrm{C}$ is cumulated, with $10^{\circ} \mathrm{C}$ subtracted, thus effective accumulative temperature is obtained as the predictive index (Gilmore and Rogers, 1958). APSIM model applies the multilinear function of temperature-phenology in the range of $0-44^{\circ} \mathrm{C}$ to express the dynamic condition of corn's phenology (Wilson et al., 1995). Parent and Tardieu (2012) established enzyme catalysis formula to express the impacts of corn genotype on temperature at high, middle and low latitudes. Although different response function and model structure have different digital results on agricultural phenology (Asseng et al., 2013; Kumudini et al., 2014), impacts of climate change on agricultural phenology have drawn academic attentions and become important interests of crop adaptation and yield prediction.

The coupling of the agricultural phenology model enhances the simulation accuracy of material exchange among earth-atmosphere boundary in the surface process model and the general circulation model and strengthens the cognition and understandings on the climatic effects of agricultural ecosystem (Betts, 2005). For instance, through vegetation transpiration effects, advanced growth of spring crop showed high inhibiting effects on the temperature rising of the East Asia (Jeong et al., 2009). Based on site and local scale data (Luyssaert et al., 2014) and model simulation results (Bagley et al., 2015), the biophysical process of the agricultural phenology period extension in temperate regions generally presents that the transpiration-cooling effects are greater than albedo-warming effects, making the temperature reduction dominated in phenology extended period. Comparing the monoculture and rotation system in the North China Plain, June is rotation's harvest time and monoculture's full-grown time, the differences in the two agricultural ecological systems encourage striking changes in latent heat flux, air temperature, precipitation and regional circulation (Jeong et al., 2014). The advancement of phenology changed crop's process like transpiration ef- 
fects and soil water circulation, and influenced the interannual variation of tornado by providing the atmosphere with more moisture (Raddatz and Cummine, 2003); and became the impact factor of floods through runoff process (Jackson et al., 2008). Therefore, research results prone to prove surface energy partitioning is the main impact process of agricultural phenology dynamic, and the primary mechanism of temperature, moisture and circulation variation.

Coupling the agricultural phenology model into the general circulation model not only provides more accurate data for the heat and water flux exchange in the atmosphere boundary layer, but the possibility of studying the interaction between climate and crop. The climate's variation in seasonal, interannual and interdecadal scale influences the dynamic of land surface process, which in turn exerts feedback effects on atmosphere through boundary layer variation, and this interactive climate-phenology model reflects the correlation between climate and agricultural ecosystem in a more real manner (Betts, 2005; Song et al., 2013). Simulation results of ECHAM5 and JSBACH coupling model had showed that phenology attributed more to precipitation than soil moisture in many regions (Bali and Collins, 2015). Osborne et al. (2007) added an annual crop subroutine into the MOSES land surface process model, the atmosphere conditions and crop growth have interactive effects in this coupling model, the crop influences climate by influencing the lower atmospheric conditions, and the changed climate alters the growth and development of crop simultaneously. This model authentically simulated the impacts of climate on seasonal growth of annual crop, and presented the measured relationship between precipitation and crop yield.

\section{Prospects}

The framework chart of this paper is as shown in Figure 1. Influenced by global warming and management measures, the agricultural phenology had changed noticeably. The planting and filling dates advanced in respond to climate warming in spring, the reproductive period prolonged in respond to yield increase and other phenology periods changed accordingly as well. The fluctuation range of agricultural phenology can reach up to one month, so it exerts noteworthy influences on the land surface process, biophysical process and climate feedback. Coupling crop model in land surface process model and general circulation model is an important method to study the impacts of phenology variation on surface energy and water balance and boundary layer characteristics. Detailed growth and development algorithm in crop model provides accurate dynamic of agricultural phenological and physiological process, improves the expressions of the land surface dynamic process in land surface process model and general circulation model, and thereby strengthen the simulations on the biophysical processes like surface albedo, net radiation, latent heat and sensible heat and the atmospheric processes like temperature, precipitation and circulation. The quantitative research on the impacts of surface phenology dynamic on biophysical process and the interactive relationship between phenology and climate is realized.

Researches performed in temperate region had showed that phenology dynamic exerted striking influences on surface energy and water balance in special times at regional scale, surface energy partitioning mechanism outweighed the albedo mechanism, and dominated the feedback effects of phenology on climate feedback. In future, the climate change in croplands calls for attentions on agricultural ecosystem's dynamic and its climatic effects 


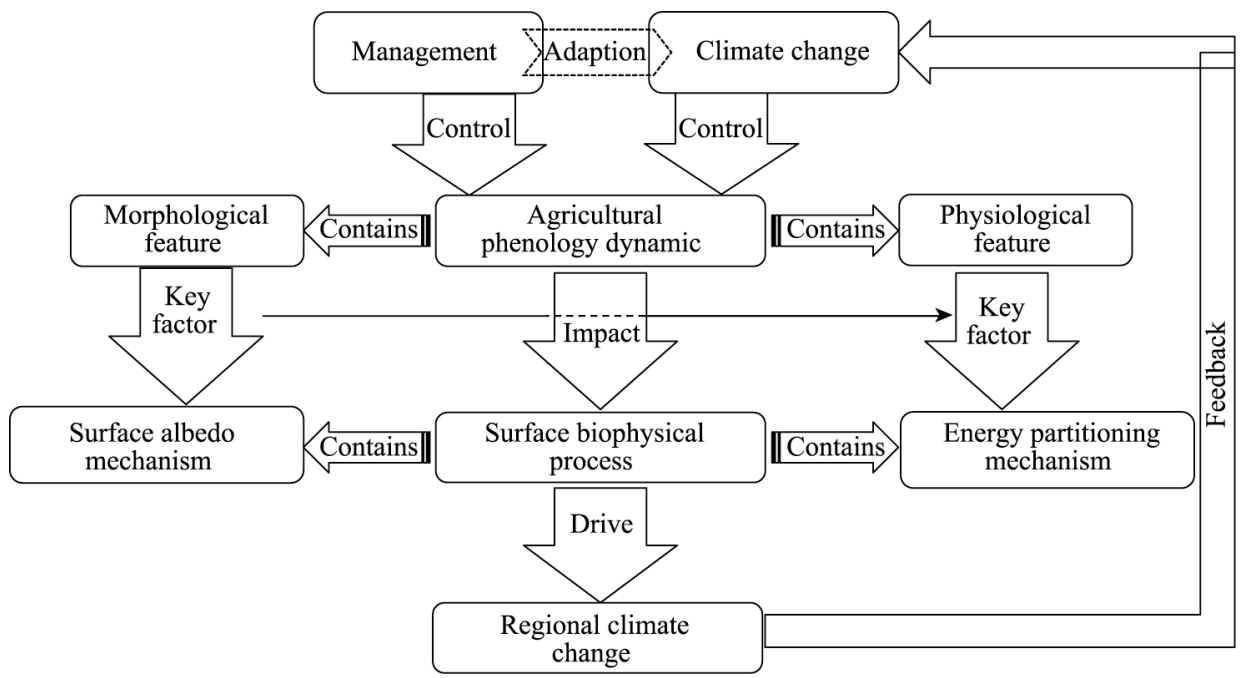

Figure 1 Flowchart of the influences of agricultural phenology dynamic on biophysical process and climate feedback

in surface biophysical ways. The following works need to be done:

1) Optimizing land surface process model by coupling crop model and strengthening the comprehensive research on the interactive action between global change and agricultural phenology dynamic. Because of the complexity of agricultural ecosystem, the existing land surface process models are not accurate in simulating agricultural ecosystem. The development of land surface process model calls for the coupling of crop model by combining surface phenology and observation data of heat and water flux.

2) Influenced by the direct proportion of near-infrared reflectivity to LAI, surface albedo often presents positive relation with LAI in field observation (Hammerle et al., 2008). However, this kind of relationship is rarely mimiced or analyzed in model simulation results. More emphasis on the relationship between crop dynamic and surface reflectivity at different spectral bands is helpful to optimize model parameters and more accurately describe the radiation budget dynamic before and after phenology variation.

3) Phenology variation changes both morphological characteristics and physiological features of crop (Balota et al., 2008; Sharma and Pannu, 2008; Xiao et al., 2012; Aisawi et al., 2015; Koester et al., 2016) Since physiological parameters are hard to be quantized, model researches are inclined to study the influential rule of morphology. However, physiological features are the main mechanism in controlling surface energy partitioning. In the past several decades, the physiological variation caused by crop renewal and its impacts on surface energy and water balance and climatic effects are an important mechanism of biophysical process.

4) Emphasis also should be laid on the differences of climatic feedback effects from agricultural phenology dynamic in different climatic regions. For example, does surface albedo mechanism surpass energy partitioning mechanism in ice and snow covered region when studying the biophysical impacts of planting advancement. In dry and wet regions, what are the differences of climatic effects with crops phenology extension? Based on their performance, different phenology management tactics should be adopted to tackle the issue of regional warming. 


\section{References}

Aisawi K A B, Reynolds M P, Singh R P et al., 2015. The physiological basis of the genetic progress in yield potential of CIMMYT spring wheat cultivars from 1966 to 2009. Crop Science, 55(4): 1749-1764.

Asseng S, Ewert F, Rosenzweig C et al., 2013. Uncertainty in simulating wheat yields under climate change. Nature Climate Change, 3(9): 827-832.

Bagley J E, Desai A R, Dirmeyer P A et al., 2012. Effects of land cover change on moisture availability and potential crop yield in the world's breadbaskets. Environmental Research Letters, 7(1): 014009. doi: 10.1088/1748-9326/1087/1081/014009.

Bagley J E, Miller J, Bernacchi C J, 2015. Biophysical impacts of climate-smart agriculture in the Midwest United States. Plant Cell and Environment, 38(9): 1913-1930.

Bali M, Collins D, 2015. Contribution of phenology and soil moisture to atmospheric variability in ECHAM5/JSBACH model. Climate Dynamics, 45(9): 2329-2336.

Balota M, William A P, Evett S R et al., 2008. Morphological and physiological traits associated with canopy temperature depression in three closely related wheat lines. Crop Science, 48(5): 1897-1910.

Betts R A, 2005. Integrated approaches to climate-crop modelling: Needs and challenges. Philosophical Transactions of the Royal Society B: Biological Sciences, 360(1463): 2049-2065.

Bondeau A, Smith P C, Zaehle S et al., 2007. Modelling the role of agriculture for the 20th century global terrestrial carbon balance. Global Change Biology, 13(3): 679-706.

Bright R M, Zhao K, Jackson R B et al., 2015. Quantifying surface albedo and other direct biogeophysical climate forcings of forestry activities. Global Change Biology, 21(9): 3246-3266.

Chang K H, Warland J S, Bartlett P A et al., 2014. A simple crop phenology algorithm in the land surface model CN-CLASS. Agronomy Journal, 106(1): 297-308.

Chen F, Xie Z, 2011. Effects of crop growth and development on land surface fluxes. Advances in Atmospheric Sciences, 28(4): 927-944.

Chen M, Griffis T J, Baker J et al., 2015. Simulating crop phenology in the Community Land Model and its impact on energy and carbon fluxes. Journal of Geophysical Research: Biogeosciences, 120(2): 310-325.

Chen Xiaoqiu, Wang Linhai, 2009. Progress in remote sensing phenological research. Progress in Geography, 28(1): 33-40. (in Chinese)

Chmielewski F M, Müller A, Bruns E, 2004. Climate changes and trends in phenology of fruit trees and field crops in Germany, 1961-2000. Agricultural and Forest Meteorology, 121(1/2): 69-78.

Dai Junhu, Wang Huanjiong, Ge Quansheng, 2013. Changes of spring frost risks during the flowering period of woody plants in temperate monsoon area of China over the past 50 years. Acta Geographica Sinica, 68(5): 593-601. (in Chinese)

de Beurs K M, Henebry G M, 2004. Land surface phenology, climatic variation, and institutional change: Analyzing agricultural land cover change in Kazakhstan. Remote Sensing of Environment, 89(4): 497-509.

de Noblet-Ducoudre N, Gervois S, Ciais P et al., 2004. Coupling the Soil-Vegetation-Atmosphere-Transfer Scheme ORCHIDEE to the agronomy model STICS to study the influence of croplands on the European carbon and water budgets. Agronomie, 24(6/7): 397-407.

Erb K H, Luyssaert S, Meyfroidt P et al., 2016. Land management: Data availability and process understanding for global change studies. Global Change Biology, 23(2): 512-533.

Eyshi Rezaei E, Siebert S, Ewert F, 2017. Climate and management interaction cause diverse crop phenology trends. Agricultural and Forest Meteorology, 233: 55-70.

Fan Deqin, Zhao Xuesheng, Zhu Wenquan et al., 2016. Review of influencing factors of accuracy of plant phenology monitoring based on remote sensing data. Progress in Geography, 35(3): 304-319. (in Chinese)

Garnaud C, Sushama L, 2015. Biosphere-climate interactions in a changing climate over North America. Journal of Geophysical Research: Atmospheres, 120(3): 1091-1108.

Ge Q S, Wang H J, Zheng J Y et al., 2014. A 170 year spring phenology index of plants in eastern China. Journal of Geophysical Research: Biogeosciences, 119(3): 301-311.

Ge Quanshen, Dai Junhu, Zheng Jingyun, 2010. The Progress of phenology studies and challenges to modern phenology research in China. Bulletin of Chinese Academy of Sciences, 25(3): 310-316. (in Chinese)

Gervois S, de Noblet-Ducoudre N, Viovy $\mathrm{N}$ et al., 2004. Including croplands in a global biosphere model: Methodology and evaluation at specific sites. Earth Interactions, 18: GB1009. doi: 10.1029/2003GB002108.

Gilmore E C, Rogers J S, 1958. Heat units as a method of measuring maturity in corn. Agronomy Journal, 50(10): 611-615.

Guillevic P, Koster R D, Suarez M J et al., 2002. Influence of the interannual variability of vegetation on the 
surface energy balance: A global sensitivity study. Journal of Hydrometeorology, 3(6): 617-629.

Hammerle A, Haslwanter A, Tappeiner U et al., 2008. Leaf area controls on energy partitioning of a temperate mountain grassland. Biogeosciences, 5(2): 421-431.

Jackson B M, Wheater H S, Mcintyre N R et al., 2008. The impact of upland land management on flooding: Insights from a multiscale experimental and modelling programme. Journal of Flood Risk Management, 1(2): 71-80.

Jeong S J, Ho C H, Jeong J H, 2009. Increase in vegetation greenness and decrease in springtime warming over east Asia. Geophysical Research Letters, 36(2): L02710. doi: 10.1029/2008GL036583.

Jeong S J, Ho C H, Piao S et al., 2014. Effects of double cropping on summer climate of the North China Plain and neighbouring regions. Nature Clim. Change, 4(7): 615-619.

Koester R P, Nohl B M, Diers B W et al., 2016. Has photosynthetic capacity increased with 80 years of soybean breeding? An examination of historical soybean cultivars. Plant Cell and Environment, 39(5): 1058-1067.

Korner C, Basler D, 2010. Phenology under global warming. Science, 327(5972): 1461-1462.

Kowalczyk E A, Stevens L E, Law R M et al., 2016. The impact of changing the land surface scheme in ACCESS(v1.0/1.1) on the surface climatology. Geoscientific Model Development, 9(8): 2771-2791.

Kumudini S, Andrade F H, Boote K J et al., 2014. Predicting maize phenology: Intercomparison of functions for developmental response to temperature. Agronomy Journal, 106(6): 2087-2097.

Leff B, Ramankutty N, Foley J A, 2004. Geographic distribution of major crops across the world. Global Biogeochemical Cycles, 18(1): GB1009. doi: 10.1029/2003GB002108

Lei H, Yang D, Lokupitiya E et al., 2010. Coupling land surface and crop growth models for predicting evapotranspiration and carbon exchange in wheat-maize rotation croplands. Biogeosciences, 7(10): 3363-3375.

Levis S, Bonan G B, Kluzek E et al., 2012. Interactive crop management in the Community Earth System Model (CESM1): Seasonal influences on land-atmosphere fluxes. Journal of Climate, 25(14): 4839-4859.

Liu F S, Tao F L, Liu J Y et al., 2016. Effects of land use/cover change on land surface energy partitioning and climate in Northeast China. Theoretical and Applied Climatology, 123(1/2): 141-150.

Liu J Y, Shao Q Q, Yan X D et al., 2016. The climatic impacts of land use and land cover change compared among countries. Journal of Geographical Sciences, 26(7): 889-903.

Lobell D B, Bala G, Duffy P B, 2006. Biogeophysical impacts of cropland management changes on climate. Geophysical Research Letters, 33(6): L06708. doi: 10.1029/2005GL025492.

Lokupitiya E, Denning S, Paustian K et al., 2009. Incorporation of crop phenology in Simple Biosphere Model (SiBcrop) to improve land-atmosphere carbon exchanges from croplands. Biogeosciences, 6(6): 969-986.

Luyssaert S, Jammet M, Stoy P C et al., 2014. Land management and land-cover change have impacts of similar magnitude on surface temperature. Nature Climate Change, 4(5): 389-393.

McGuire A D, Chapin F S, Walsh J E et al., 2006. Integrated regional changes in arctic climate feedbacks: Implications for the global climate system. Annual Review of Environment and Resources, 31: 61-91.

Mirschel W, Wenkel K O, Schultz A et al., 2005. Dynamic phenological model for winter rye and winter barley. European Journal of Agronomy, 23(2): 123-135.

Morin X, Lechowicz M J, Augspurger C et al., 2009. Leaf phenology in 22 North American tree species during the 21 st century. Global Change Biology, 15(4): 961-975.

Mueller N D, Butler E E, McKinnon K A et al., 2016. Cooling of US Midwest summer temperature extremes from cropland intensification. Nature Climate Change, 6(3): 317-324.

Oguntunde P G, van de Giesen N, 2004. Crop growth and development effects on surface albedo for maize and cowpea fields in Ghana, West Africa. International Journal of Biometeorology, 49(2): 106-112.

Olesen J E, Borgesen C D, Elsgaard L et al., 2012. Changes in time of sowing, flowering and maturity of cereals in Europe under climate change. Food Additives and Contaminants Part A: Chemistry Analysis Control Exposure \& Risk Assessment, 29(10): 1527-1542.

Osborne T M, Lawrence D M, Challinor A J et al., 2007. Development and assessment of a coupled crop-climate model. Global Change Biology, 13(1): 169-183.

Oteros J, Garcia-Mozo H, Botey R et al., 2015. Variations in cereal crop phenology in Spain over the last twenty-six years (1986-2012). Climatic Change, 130(4): 545-558.

Parent B, Tardieu F, 2012. Temperature responses of development processes have not been affected by breeding in different ecological areas for 17 crop species. New Phytologist, 194(3): 760-774.

Penuelas J, Rutishauser T, Filella I, 2009. Phenology feedbacks on climate change. Science, 324(5929): 887-888.

Pielke R A, Adegoke J, Beltran-Przekurat A et al., 2007. An overview of regional land-use and land-cover impacts on rainfall. Tellus Series B: Chemical and Physical Meteorology, 59(3): 587-601. 
Raddatz R L, Cummine J D, 2003. Inter-annual variability of moisture flux from the prairie agro-ecosystem: Impact of crop phenology on the seasonal pattern of Tornado Days. Boundary-Layer Meteorology, 106(2): 283-295.

Richardson A D, Keenan T F, Migliavacca M et al., 2013. Climate change, phenology, and phenological control of vegetation feedbacks to the climate system. Agricultural and Forest Meteorology, 169: 156-173.

Sacks W J, Kucharik C J, 2011. Crop management and phenology trends in the US Corn Belt: Impacts on yields, evapotranspiration and energy balance. Agricultural and Forest Meteorology, 151(7): 882-894.

Schwartz M D, Ahas R, Aasa A, 2006. Onset of spring starting earlier across the Northern Hemisphere. Global Change Biology, 12(2): 343-351.

Sharma K D, Pannu R K, 2008. Physiological response of wheat (Triticum durum L.) to limited irrigation. Journal of Agrometeorology, 10(2): 113-117.

Shi Wenjiao, Tao Fulu, Zhang Zhao, 2012. Identifying contributions of climate change to crop yields based on statistical models: A review. Acta Geographica Sinica, 67(9): 1213-1222. (in Chinese)

Song Y, Jain A K, McIsaac G F, 2013. Implementation of dynamic crop growth processes into a land surface model: Evaluation of energy, water and carbon fluxes under corn and soybean rotation. Biogeosciences, 10(12): 8201-8201.

Tao F L, Zhang S A, Zhang Z, 2012. Spatiotemporal changes of wheat phenology in China under the effects of temperature, day length and cultivar thermal characteristics. European Journal of Agronomy, 43: 201-212.

Tao F L, Zhang S, Zhang Z et al., 2014. Maize growing duration was prolonged across China in the past three decades under the combined effects of temperature, agronomic management, and cultivar shift. Global Change Biology, 20(12): 3686-3699.

Tsarouchi G M, Buytaert W, Mijic A, 2014. Coupling a land-surface model with a crop growth model to improve ET flux estimations in the Upper Ganges basin, India. Hydrology and Earth System Sciences, 18(10): 4223-4238.

Tsvetsinskaya E A, Mearns L O, Easterling W E, 2001. Investigating the effect of seasonal plant growth and development in three-dimensional atmospheric simulations. Part I: Simulation of surface fluxes over the growing season. Journal of Climate, 14(5): 692-709.

Van den Hoof C, Hanert E, Vidale P L, 2011. Simulating dynamic crop growth with an adapted land surface model - JULES-SUCROS: Model development and validation. Agricultural and Forest Meteorology, 151(2): $137-153$.

Wang E, Engel T, 1998. Simulation of phenological development of wheat crops. Agricultural Systems, 58(1): $1-24$.

Wang Z, Chen J, Li Y et al., 2016. Effects of climate change and cultivar on summer maize phenology. International Journal of Plant Production, 10(4): 509-525.

Wilson D R, Muchow R C, Murgatroyd C J, 1995. Model analysis of temperature and solar radiation limitations to maize potential productivity in a cool climate. Field Crops Research, 43(1): 1-18.

Xiao D P, Moiwo J P, Tao F L et al., 2015. Spatiotemporal variability of winter wheat phenology in response to weather and climate variability in China. Mitigation and Adaptation Strategies for Global Change, 20(7): 1191-1202.

Xiao D P, Qi Y Q, Shen Y J et al., 2016. Impact of warming climate and cultivar change on maize phenology in the last three decades in North China Plain. Theoretical and Applied Climatology, 124(3/4): 653-661.

Xiao D P, Tao F L, Liu Y J et al., 2013. Observed changes in winter wheat phenology in the North China Plain for 1981-2009. International Journal of Biometeorology, 57(2): 275-285.

Xiao Y G, Qian Z G, Wu K et al., 2012. Genetic gains in grain yield and physiological traits of winter wheat in Shandong Province, China, from 1969 to 2006. Crop Science, 52(1): 44-56.

Yuan Zaijian, Shen Yanjun, Chu Yingmin et al., 2010. Characteristics and simulation of heat and $\mathrm{CO}_{2}$ fluxes over a typical cropland during the winter wheat growing in the North China Plain. Environmental Science, 31(1): 41-48. (in Chinese)

Zhang X, Tang Q, Zheng J et al., 2013. Warming/cooling effects of cropland greenness changes during 1982-2006 in the North China Plain. Environmental Research Letters, 8(2): 024038.

Zheng Jingyun, Liu Yand, Ge Quansheng et al., 2015. Spring phenodate records derived from historical documents and reconstruction on temperature change in Central China during 1850-2008. Acta Geographica Sinica, 70(5): 696-704. (in Chinese)

Zhou Guangsheng, 2015. Research prospect on impact of climate change on agricultural production in China. Meteorological and Environmental Sciences, 38(1): 80-94. (in Chinese) 